\title{
THE USE OF ANALYTICAL METHODS FOR QUALITY CONTROL OF PROMISING ACTIVE PHARMACEUTICAL INGREDIENTS AMONG DERIVATIVES OF 4-OXO- QUINOLINE-3-PROPANOIC ACIDS
}

\author{
V.O.Zubkov, N.I.Ruschak, M.M.Suleiman, A.O.Devyatkina, I.S.Gritsenko \\ National University of Pharmacy \\ Ivano-Frankivsk National Medical University
}

Key words: antimicrobial resistance; quinolin-4-one; propanoic acid; standardization; quality control; NMR, LC-MS/MS

\begin{abstract}
Due to a global increase of microbial resistance to antimicrobial drugs the search for new antibiotics is vital for modern medicinal chemistry. 3-Quinolin-4-one propanoic acids have the molecular similarity with fluoroquinolone antibiotics and are prospective scaffold to create antimicrobial drugs. On the example of 3-(2-methyl-4-oxo-1,4-dihydroquinoline-3-yl) propanoic acid the analytical methods that can be used for quality control of promising active pharmaceutical ingredients (API) among derivatives of 3-(2-methyl-4 oxo-1,4-dihydroquinoline-3-yl) propanoic acids have been analyzed and tested. The

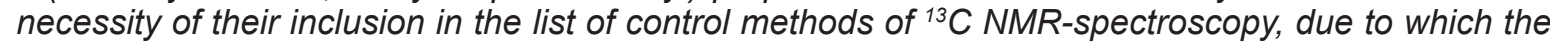
problem of the tautomeric forms of 3-(2-methyl-4-oxo-1,4-dihydroquinoline-3-yl) propanoic acid is uniquely solved, has been shown. Specific related substances, which are by-products of the synthesis of 3-(2-methyl-4-oxo-1,4-dihydroquinoline-3-yl) propanoic acid - 1,2,3,4,9,10- hexahydroacridine2,9-dione and 6a-hydroxy-5,6,6a, 8,9,14,15,16a, 17,18-decahydro-7,16-dioxa -5.14-diazaheptacene9,18-dione, have been identified using liquid chromatography-mass spectrometry (LC-MS/MS). Recommendations for the use of UV- and IR-spectroscopy to develop quality control methods for 3-(2-methyl-4-oxo-1,4-dihydroquinoline-3-yl) propanoic acid have been proposed.
\end{abstract}

The antimicrobial resistance (AMR) to drugs has now become one of the biggest threats to the global health. [10-11]. In the world many spread infections become resistant to antimicrobial drugs used to treat them. As a result, the number of diseases avalanche increases, including fatalities related to AMR [4]. The World Health Organization (WHO) is the focal point of efforts to combat AMR. In May, 2015, the 68-th Assembly of the WHO adopted a Global Plan of Action to combat resistance to antimicrobial agents, in which the unanimous opinion that AMR is a huge threat to human health is expressed [6]. One of the five strategic objectives of this document is connected with intensification of the search for new antimicrobial agents and creation of favourable conditions for the solution of this problem. Previously, it was shown at the Department of Medicinal Chemistry of the National University of Pharmacy that derivatives of 3 (2-methyl-4-oxo-1,4-dihydroquinoline-3-yl) propanoic acids exhibited a broad spectrum of the antibacterial activity and could be considered as promising scaffolds for searching new antibiotics [12]. The development of methods of standardization of substances and selection of validated methods suitable for quality control occupy an important place among the stages of introduction of drugs in medical practice. The aim of this study was to substantiate and select the analytical methods that can be used as a basis for determining the quality of promising active pharmaceutical ingredients (API) among derivatives of 4-oxo- quinoline-3-propanoic acids on the example of 3-(2-methyl-4-1,4-oxo dihydroquinoline-3-yl) propanoic acid.

Materials and Methods

3-(2-Methyl-4-oxo-1,4-dihydroquinoline-3-yl) propanoic acid was obtained according to the method [14] and purified by several recrystallizations from ethanol and propanol-2. ${ }^{1} \mathrm{H}$ and ${ }^{13} \mathrm{C}$ NMR-spectra were recorded on a "Bruker Avance-400" device in DMSO- ${ }_{6}$ at operating frequencies of $400 \mathrm{MHz}$ for ${ }^{1} \mathrm{H}$ NMR and $100 \mathrm{MHz}$ for ${ }^{13} \mathrm{C}$-NMR, TMS was the internal standard. The IRspectrum was recorded on a "Bruker Tensor 27 FT-IR" spectrophotometer in the $4000-400 \mathrm{~cm}^{-1}$ in tablets with anhydrous potassium bromide (the concentration of the substance was $1 \%$ ).

The electronic absorption spectrum was recorded on a "Specord 200 "AnalitykJena" spectrophotometer in the methanol solution (the concentration of the substance was $\left.5 \times 10^{-4} \%\right)$. The chromatography-mass spectrometry studies (LC-MS/MS) were carry out using an Agilent 1290 liquid chromatograph equipped with a diode array, a four-canal pump for forming a low pressure gradient, an automatic sample dispenser and the column thermostat. As a mass selective detector an Agilent 6530 Q-TOF tandem quadrupole time-of-flight mass spectrometer was used. The "MassHunter" software was used for processing of the measurement results obtained. The "ChemAxon" chemo-information software was used to determine the molecular similarity of structures [8]. 
The procedure for liquid chromatography-mass spectrometry of 3-(2-methyl-4-oxo-1,4-dihydroquinoline-3-yl) propanoic acid.

Preparation of the test solution of 3-(2-methyl-4-oxo1,4-dihydroquinoline-3-yl) propanoic acid: place $100 \mathrm{mg}$ of the substance in a $100 \mathrm{ml}$ volumetric flask, add $75 \mathrm{ml}$ of acetonitrile $R$ and place on an ultrasonic bath to complete dissolution. Cool the solution, dilute it to the volume with acetonitrile $R$ and mix. Chromatograph alternately the test solution and the reference solution (solvent) to obtain the number of parallel chromatograms (n) for each of the solutions not less than in verification of the chromatographic system suitability under the following conditions $(\mathrm{C} 8)$ :

- column with the size of $50 \times 4.6 \mathrm{~mm}$ filled with the sorbent derivatized silica gel octadecyl (L1), the particle size $-1.7 \mu \mathrm{m}$, or the similar column satisfying the requirements of "Chromatographic system suitability" section of the State Pharmacopoeia of Ukraine;

- the flow rate $-1 \mathrm{ml} / \mathrm{min}$;

- the column thermostat temperature $-30^{\circ} \mathrm{C}$;

- mobile phase A: $0.005 \mathrm{M}$ solution of ammonium formate in water $R$ degassed in any convenient method;

- mobile phase B: $0.005 \mathrm{M}$ ammonium formate solution in acetonitrile $R$ - water $R$ (90:10) degassed by any convenient method;

- the elution mode - gradient:

\begin{tabular}{|c|c|c|c|}
\hline Time, min & $\begin{array}{c}\text { Mobile } \\
\text { phase A }\end{array}$ & $\begin{array}{c}\text { Mobile } \\
\text { phase B }\end{array}$ & Elution mode \\
\hline $0-1$ & 100 & 0 & Isocratic \\
\hline $1-5$ & $100 \rightarrow 10$ & $0 \rightarrow 90$ & Linear gradient \\
\hline $5-6$ & $10 \rightarrow 100$ & $90 \rightarrow 0$ & Linear gradient \\
\hline $6-10$ & 100 & 0 & Isocratic \\
\hline
\end{tabular}

- the injection volume - $1.0 \mu \mathrm{l}$;

- the detector - a mass spectrometer (Q-TOF).

Settings of the detector:

- the ionization type - positive, electrospray (+ESI);

- the measurement mode - scanning in the mass range of 10-1000 $\mathrm{AU}$;

- the nitrogen temperature $-350^{\circ} \mathrm{C}$;

- the nitrogen flow $-10 \mathrm{ml} / \mathrm{min}$;

- the pressure at the nebulizer-35 PSI;

- the voltage at the capillary $-4 \mathrm{kV}$.

The MS/MS mode was used for identification of the substances detected. Using this mode ions of the preliminarily fixed weight were accumulated, and mass spectra were recorded.

\section{Results and Discussion}

By its chemical structure 3-(2-methyl-4-oxo-1,4-dihydroquinoline-3-yl) propanoic acid $\mathbf{1}$ has the molecular similarity with 4-oxo-1,4-dihydroquinoline-3-carboxylic acid $\mathbf{2}$ known as the core scaffold for a large class of modern antibiotics - fluoroquinolones 3. (Fig. 1).

Calculation of molecular similarity for 2D structures between acids 1 and $\mathbf{2}$ by Tanimoto index showed a moderate degree of similarity of these compounds 0.55 (range $0-1$ index values; 0 - the absence of similarity between the structures, 1 - complete similarity) [9]. If we operate in comparison with 3D structures of these acids by the method of maximum common subsystems (maximum common substructures - MCS), an increase in the index 3D Tanimoto to 0.68 can be observed, and it is close to a good degree of molecular similarity between two structures. Accordingly, at first the articles in Pharmacopoeias of Ukraine (SPhU), Europe (Ph. Eur.) and the USA (USP) [1-2, 3, 5] related to fluoroquinolones were analyzed to determine the range of the group analytical methods that can be used in developing methods of quality control for APIs, which are derived from 3-(2-R-4-oxo-1,4-dihydroquinoline-3-yl) propanoic acids.

Currently, the quantitative composition of medicines of fluoroquinolone antibiotics included in national pharmacopoeias is as follows: Ukraine - 3, the European Council-10, USA - 8 medicines. Liquid chromatography, which is mostly presented in the sections "Purity Test" (Fig. 2), leads in the aggregate numerical ratio in all the pharmacopoeias among the physical and chemical methods used for the analysis of fluoroquinolone drugs.

For the quantitative determination of substances in pharmacopoeias the titrimetric methods of analysis are mainly selected, while liquid chromatography in this section takes the second place by incidence in the pharmacopoeial articles.

Based on this analysis only consideration of instrumental methods of analysis for quality control of 3-(2methyl-4-oxo-1,4-dihydroquinoline-3-yl) propanoic acid, namely IR-, UV-spectroscopy and liquid chromatography, was taken into account. However, if the structural features of quinolin-4-ones, namely the probability of appearance of prototropic tautomerism (Fig. 3) and, as a consequence, the possibility of the existence of the heterocycle in the 4-oxo and 4-hydroxy forms are considered, then the use of only the abovementined instruments is insufficient when developing methods of quality control for derivatives of 3-quinolin-4-one propanoic acids.<smiles>Cc1[nH]c2ccccc2c(=O)c1CCC(=O)O</smiles>

1<smiles>O=C(O)c1c[nH]c2ccccc2c1=O</smiles>

2<smiles>[R15]N([R2])c1cc2c(cc1F)c(=O)c(C(=O)O)cn2[R15]</smiles>

$\mathrm{R}_{3}$

Fig. 1. The molecular similarity of quinoline-4-ones having the antibacterial activity. 


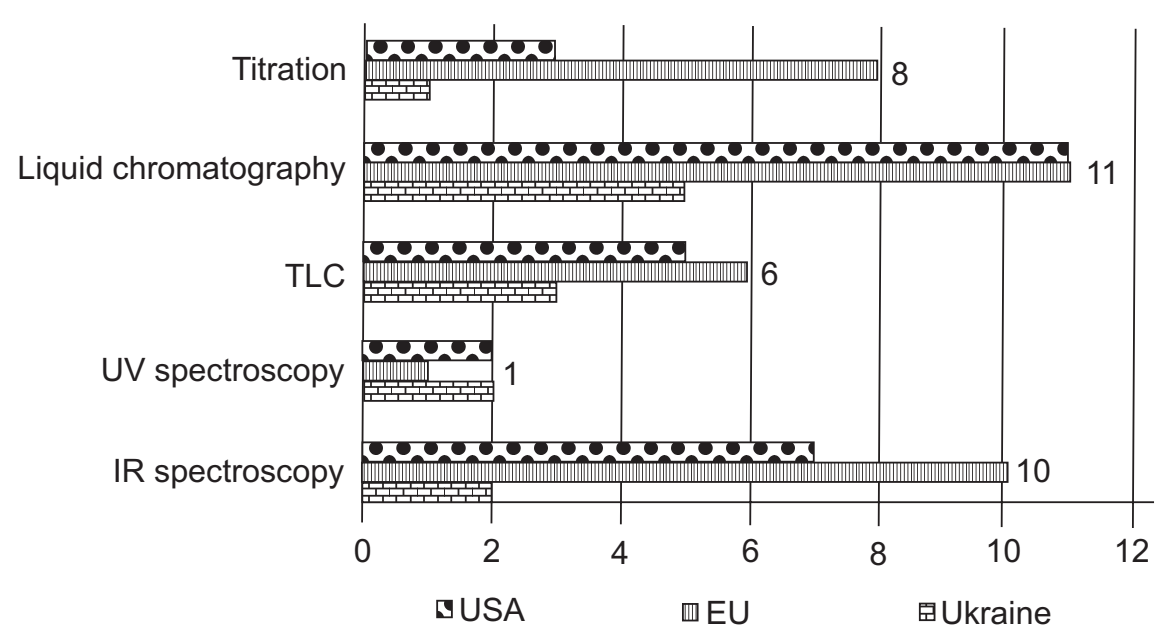

Fig. 2. The numerical application of methods of analysis for fluoroquinolones in the USP, Ph. Eur. and SPhU (Identification, Impurity, Assay).<smiles>Cc1[nH]c2ccccc2c(=O)c1CCC(=O)O</smiles><smiles></smiles>

Fig. 3. Quinoline-quinolone tautomerism for 3-(2-methyl-4-oxo-1,4-dihydroquinoline-3-yl) propanoic acid.

X-ray diffraction analysis and NMR-spectroscopy are used to solve the problem of the structural isomerism of organic compounds. Based on the analysis of world pharmacopoeias these methods are also pharmacopoeal although not as common as other physical and chemical methods of analysis (Fig. 4).

From the perspective of development of the quality control methods in those cases when a substance possesses stereoisomerism or potential tautomerism the more rational and informative method is NMR-spectroscopy, in our opinion, since it allows to receive information on the structure of substances in solutions.

To identify 3-(2-methyl-4-oxo-1,4-dihydriquinoline3 -yl) propanoic acid we suggested to include the method of ${ }^{1} \mathrm{H}$ and ${ }^{13} \mathrm{C}$ of NMR-spectroscopy to the list of the analytical procedures, which might be applied for quality control of this class of chemical compounds. In the spectrum of ${ }^{1} \mathrm{H}$ NMR in DMSO- $\mathrm{d}_{6}$ the following signals are observed: singlets of the $\mathrm{OH}$ carboxylic group

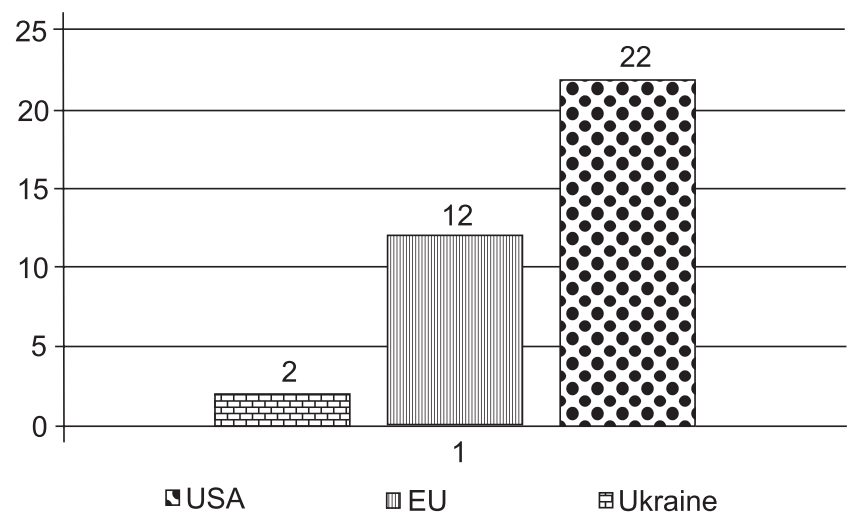

Fig. 4. The number of articles in the USP, Ph. Eur. and SPhU with NMR-spectroscopy. and $\mathrm{NH}$ of the quinoline cycle at 12.07 and $11.45 \mathrm{ppm}$ (Fig. 5). Aromatic protons of the benzol ring of the quinoline cycle are the ABCD system, and their signals are located on the spectrum in the order according to their chemical shifts and the character of multiplicity. The signal of proton in position $\mathrm{C} 5$ of the heterocycle $(5 \mathrm{H})$ is observed at $8.03 \mathrm{ppm}(\mathrm{dd}, \mathrm{J}=8.1,1.5 \mathrm{~Hz}, 1 \mathrm{H})$; the signal of proton $(6 \mathrm{H})$ is observed at $7.57 \mathrm{ppm}$ (ddd, $\mathrm{J}=8.4$, $6.9,1.5 \mathrm{~Hz}, 1 \mathrm{H})$; the signal of proton $(8 \mathrm{H})$ is located in the area of 7.49-7.41 ppm $(\mathrm{m}, 1 \mathrm{H})$; the signal of proton $(7 \mathrm{H})$ is observed at $7.24 \mathrm{ppm}(\mathrm{ddd}, \mathrm{J}=8.1,6.9,1.1 \mathrm{~Hz}, 1 \mathrm{H})$.

The signals of aliphatic protons appear in the area of strong fields and have the following location: signals of the $\mathrm{CH}_{2}$ group located directly next to the carboxyl group are observed at $2.69 \mathrm{ppm}(\mathrm{dd}, \mathrm{J}=8.5,6.9 \mathrm{~Hz}$, $2 \mathrm{H}$ ); the signals of protons of the methylene group in the quinoline heterocycle are observed at $2.37 \mathrm{ppm}(\mathrm{dd}$, $\mathrm{J}=8.6,7.0 \mathrm{~Hz}, 2 \mathrm{H}$ ), and the signal of the methyl group is displayed at $2.41 \mathrm{ppm}$ as a singlet $(\mathrm{s}, 3 \mathrm{H})$.

The one-dimensional ${ }^{1} \mathrm{H}$ NMR-spectroscopy does not allow to explain clearly the question of belonging the substance to the 4-oxo and 4-hydroxy form. Since the chemical shifts of protons are determined mainly by the diamagnetic component of the shielding constant $\sigma_{\mathrm{d}}$, and paramagnetic contribution $\sigma_{\mathrm{d}}$ is not significant and is corrective. Substituents have a great influence on the value of the chemical shift $\delta\left({ }^{1} \mathrm{H}\right)$ together with magnetic anisotropy of the neighbouring groups, effects of the ring currents and electric field, hydrogen bonds and the intermolecular interaction with the solvent [7]. In ${ }^{13} \mathrm{C}$ NMRspectroscopy the position of the signals of the carbon nuclei is stipulated mainly by the paramagnetic contribution to the shielding constant $\sigma_{\mathrm{p}}$. Therefore, intra- and intermolecular effects (in ppm) are close in size with 


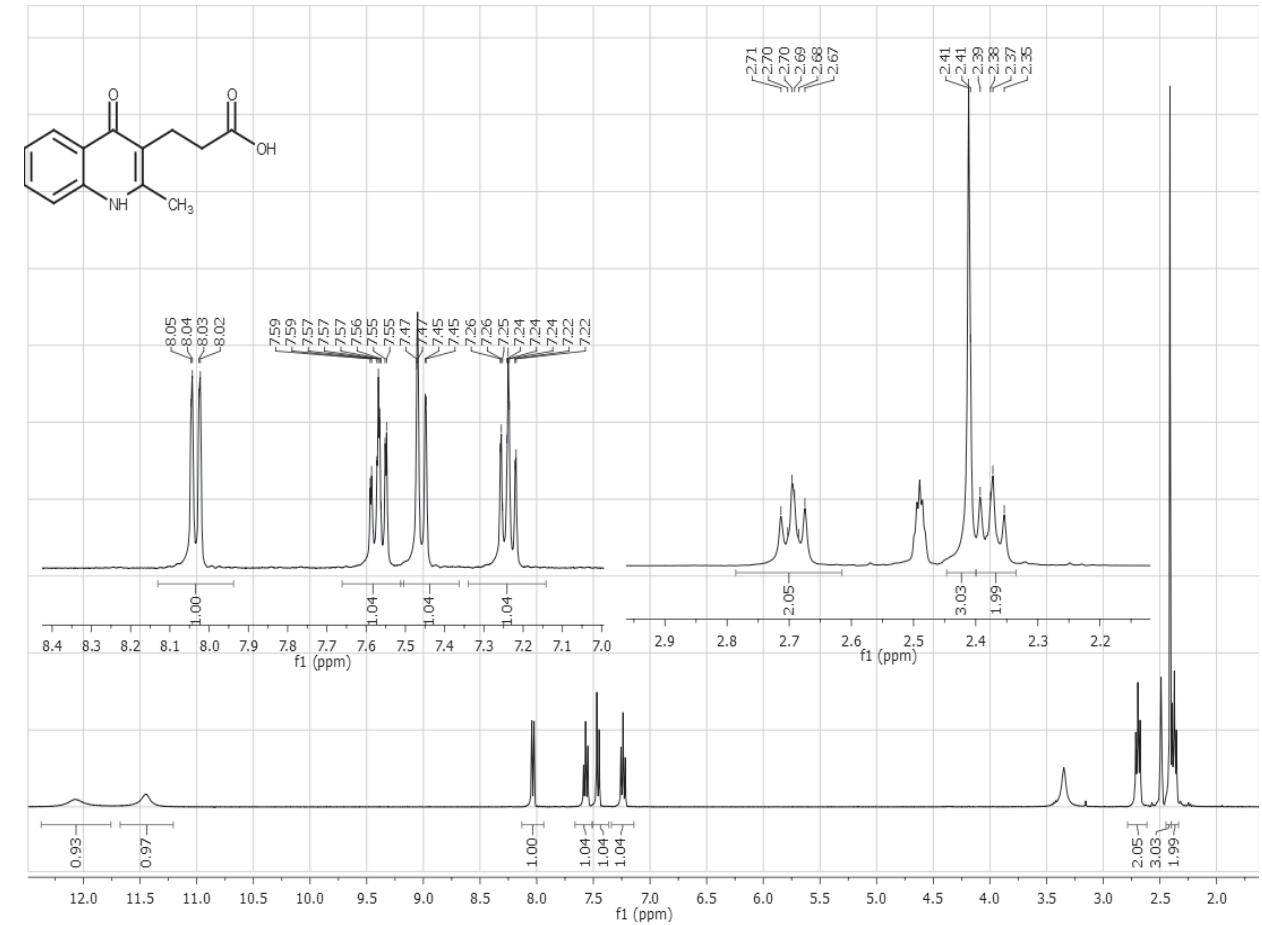

Fig. 5. The ${ }^{1} \mathrm{H}$ NMR-spectrum of 3-(2-methyl-4-oxo-1,4-dihydroquinoine-3-yl) propanoic acid in DSMO- $\mathrm{d}_{6}$.

the same effects in ${ }^{1} \mathrm{H}$ NMR-spectroscopy, but are very small in comparison with the total value of the chemical shift $\delta\left({ }^{13} \mathrm{C}\right)$.

Previously, we applied ${ }^{13} \mathrm{C}$ NMR-spectroscopy and quantum-chemical calculations with different approximations to show an evident difference in chemical shifts of the carbon atoms at $\mathrm{C} 4$ position of 4-oxo tautomeric form (174-177 ppm) and 4-hydroxy form (160 ppm) [13]. This allows identifying easily in which tautomeric form the substance under study is, and, therefore, these values can be used as an analytical criterion when developing quality control methods for derivatives of 3-quinolin4-on propanoic acid in identification sections and purity tests.

In the ${ }^{13} \mathrm{C}$ NMR-spectrum of 3-(2-methyl-4-oxo-1,4dihydroquinoline-3-yl) propanoic acid recorded within the APT experiment the following signals of nuclei carbons are observed: $175.48 \mathrm{ppm}$ ( $\mathrm{C} 1$ of propanoic acid), $174.41 \mathrm{ppm}$ (C4 of quinolone), $146.42 \mathrm{ppm}$ (C8a of quinolone), $139.10 \mathrm{ppm}$ (C2 of quinolone), $131.03 \mathrm{ppm}$ (C7 of quinolone), $124.89 \mathrm{ppm}$ (C5 of quinolone), $123.29 \mathrm{ppm}$ (C6 of quinolone), $122.41 \mathrm{ppm}$ (C4a of quinolone), $117.45 \mathrm{ppm}$ (C8 of quinolone), $117.30 \mathrm{ppm}$ (C of quinolone), $32.62 \mathrm{ppm}$ (C2 of propanoic acid), $21.00 \mathrm{ppm}$ (C3 of propanoic acid), $17.55 \mathrm{ppm}$ ( $\mathrm{C} 1$ of the methyl group) (Fig. 6).

In the modern pharmaceutical chemistry while developing quality control methods chromatography occupies the leading place among the other methods of physical and chemical analysis. If a chromatograph is equipped with a mass-spectrometric detector, the range of analytical tasks which can be solved with assistance

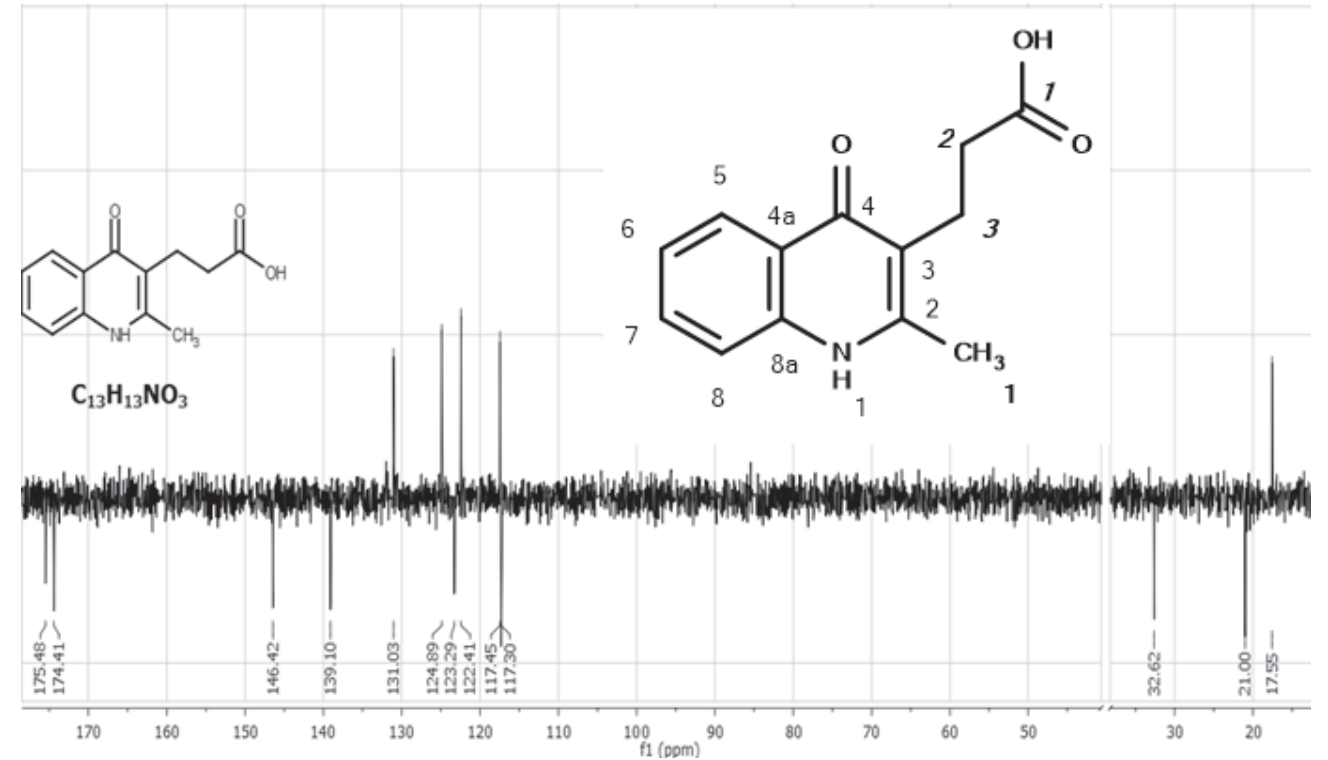

Fig. 6. Numeration and the ${ }^{3} \mathrm{C}$ NMR spectrum of 3-(2-methyl-4-oxo-1,4-dihydroquinoline-3-yl) propanoic acid in DSMO- $\mathrm{d}_{6}$ (APT experiment). 

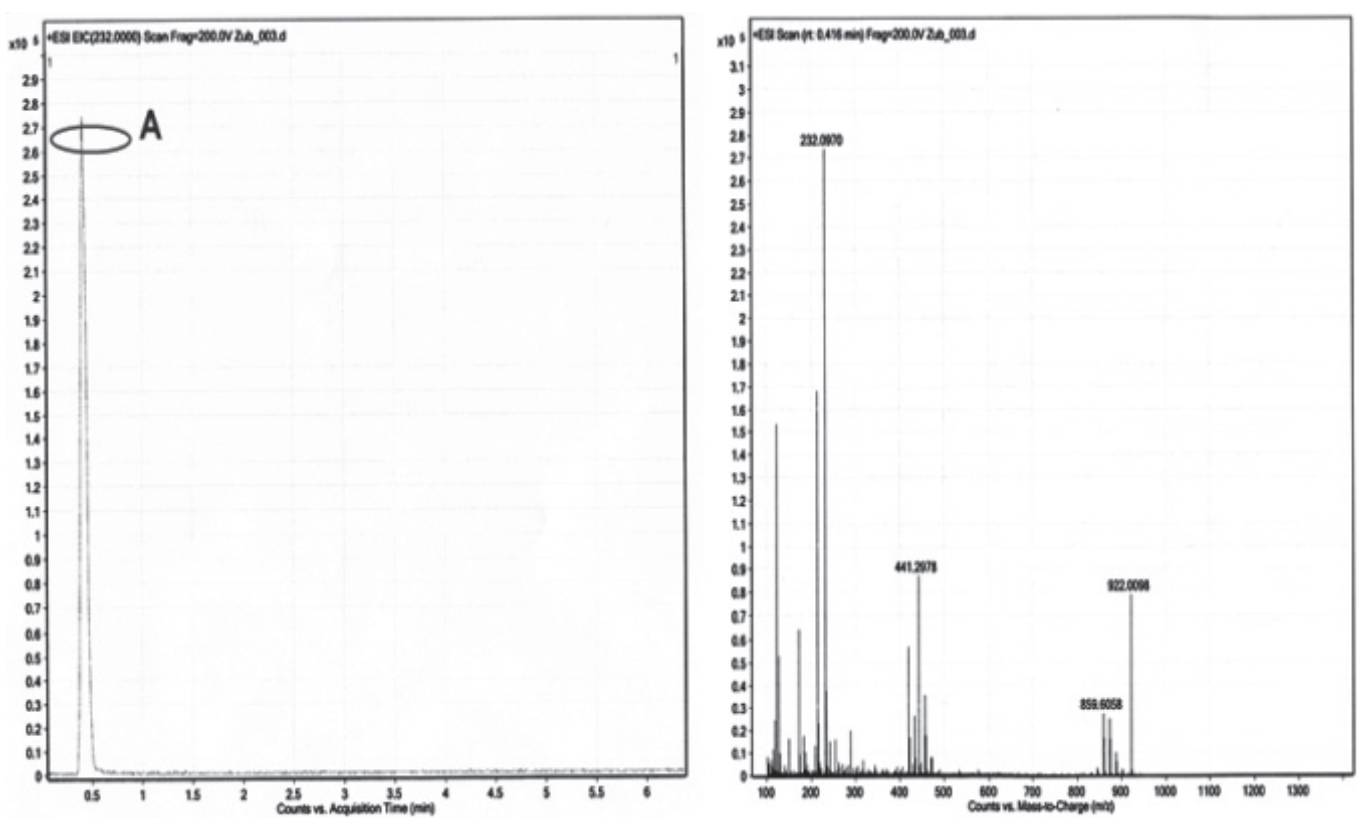

Fig. 7. The chromatogram of the total ion current of the sample and the mass spectrum (m/z) of peak A in the study of 3-(2-methyl-4-oxo-1,4dihydroquinoline-3-yl) propanoic acid.

of a set of such devices is vastly increasing. For 3-(2methyl-4-oxo-1,4-dihydroquinoline-3-yl) propanoic acid the LC/MS-MS method was applied to identify and determine specific impurities in the substance. The tests were conducted at the premises of the National University of Pharmacy under the supervision of Ph. D. Khanin V.A.

In Fig. 7 and 8 the results of the gas chromato-massspectrometric studies are presented. They show that the test sample contains three components: with the molecular weight of 213 atomic units (Impurity $A$ ), 231 a.u. (the main substance) and 440 a.u. (Impurity $B$ ), (molecular ions m/z $214(\mathrm{M}+\mathrm{H})+; 232(\mathrm{M}+\mathrm{H})+; 441(\mathrm{M}+\mathrm{H})+$, respectively). Such set of impurities is explained by the method of obtaining 3-(2-methyl-4-oxo-1,4-dihydroquinoline-3-yl) propanoic acid synthesized from 3-[(dimethylamino)methyl]-2-methyl-1,4-dihydroquinoline-4-one 5 in four steps [14] (Scheme 1).

Impurity $A$ has the molecular weight of 18 a.u. less than the main substance. It is perfectly clear that such compound is obtained by elimination of a water molecule from 3 (2-methyl-4-oxo-1,4-dihydro-quinoline-3-yl) propanoic acid $\mathbf{1}$, and the only logical direction, in which dehydration can pass, is the intramolecular condensation with formation of 1,2,3,4,9,10-2,9-hexahydroacri-

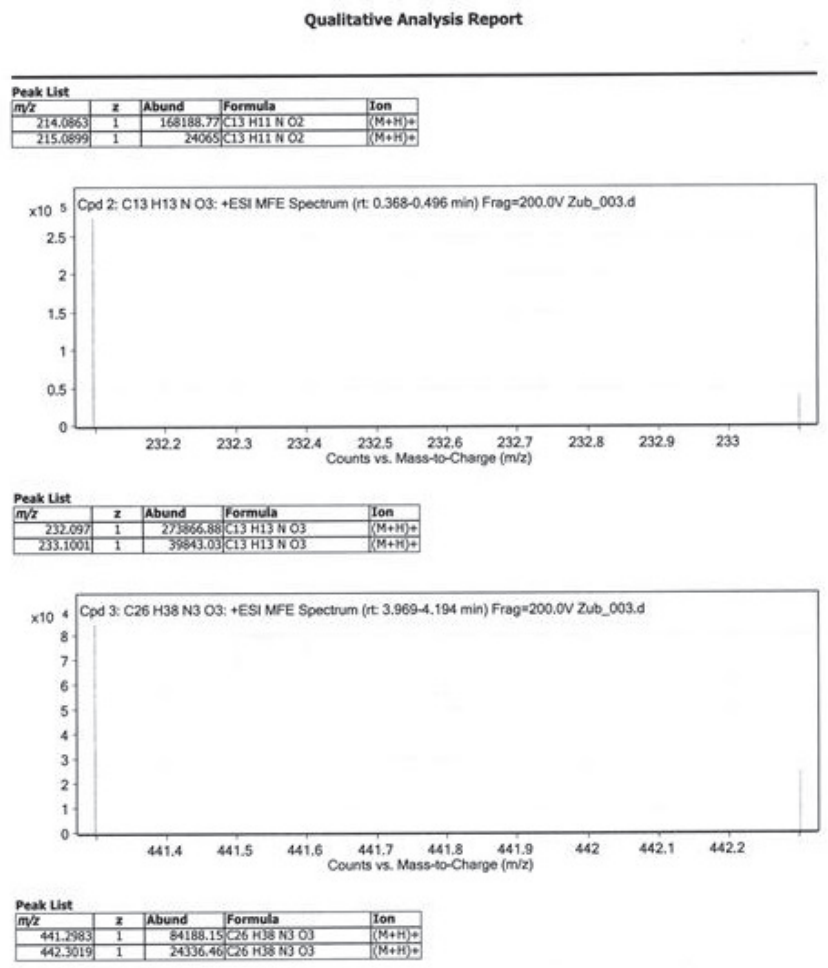<smiles>O=C1CCc2c([nH]c3ccccc3c2=O)C1</smiles>

$\mathrm{C}_{13} \mathrm{H}_{11} \mathrm{NO}_{2}$ M.w. 213,24<smiles>Cc1[nH]c2ccccc2c(=O)c1CCC(=O)O</smiles>

$\mathrm{C}_{13} \mathrm{H}_{13} \mathrm{NO}_{3}$ M.w. 231,25<smiles></smiles>

Impurity B

\section{Main substance}<smiles>C1CCCC1</smiles>

Fig. 8. Substances identified in the sample of 3-(2- methyl-4-oxo-1,4-digidpohinolin-3-yl) propanoic acid (LC/MS-MS). 
<smiles>CCOC(=O)COC(=O)CC(Cc1c(C)[nH]c2ccccc2c1=O)C(=O)OCC</smiles><smiles></smiles><smiles>Cc1[nH]c2ccccc2c(=O)c1CC(C(=O)O)C(=O)O</smiles>

8<smiles>Cc1[nH]c2ccccc2c(=O)c1CCC(=O)O</smiles>

1<smiles>O=C1CCc2c([nH]c3ccccc3c2=O)C1</smiles>

9

Scheme 2

dine-2,9-dione 9 (Scheme 2). To the benefit of this fact is that the last stage of the synthesis is carried out under rather rigid conditions - long boiling in 50\% aqueous sulphuric acid that promotes acylation of the methyl group with the aliphatic carboxyl group in position $\mathrm{C} 2$ of quinolone.

Impurity $B$ with the molecular weight of 440 a.u. was considered as a product of dimerization with involvement of either the main compound or impurity $A$, or both of them. After the logical analysis of the synthetic potential conducted and the possible ways of interaction between these compounds the structure of 6a-hydroxy5,6,6a, 8,9,14,15,16a, 17,18-decahydro-7,16-dioxa-5,14diazaheptacen-9,18-dione $\mathbf{1 2}$ was proposed as impurity $B$. The key role in the mechanism of its formation is also played by conditions under which decarboxylation of 2-[(2-methyl-4-oxo-1,4-dihydroquinoline-3-yl) methyl] propanedioic acid $\mathbf{8}$ (Scheme 2) occurs; and it can be assumed that the synthesis is conducted with involvement of two molecules of $1,2,3,4,9,10$-hexahydroacridine-2,9-dione 9 according to Scheme 3.

The scheme of dimerization proposed is possible, it is in accordance with the basic principles of organic chemistry, and the molecular weight of such compound coincides with the weight of impurity $B$ found experimentally.

The information on related substances obtained by the LC-MS/MS analysis of 3-(2-methyl-4-oxo-1,4-dihydroquinoline-3-yl) propanoic acid is important for the further research in the field of searching and introducing new promising biologically active compounds among derivatives of 4-oxo-quinoline-3-alkylcarboxylic acids. On the grounds of this information the following conclusions can be made:
2<smiles></smiles><smiles>O=c1c2c([nH]c3ccccc13)CC=C(OCCC1C=C(O)Cc3[nH]c4ccccc4c(=O)c31)C2</smiles>
$\mathrm{H}^{+}: \mathrm{H}_{2} \mathrm{O}$

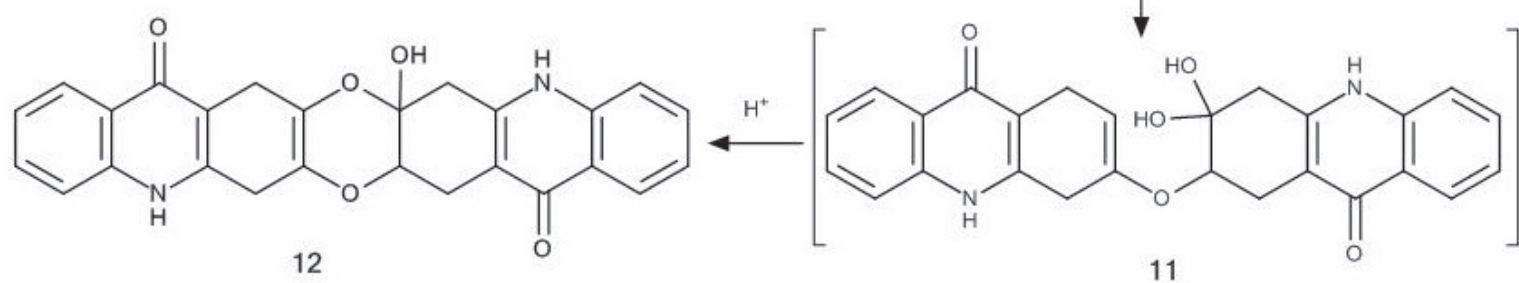




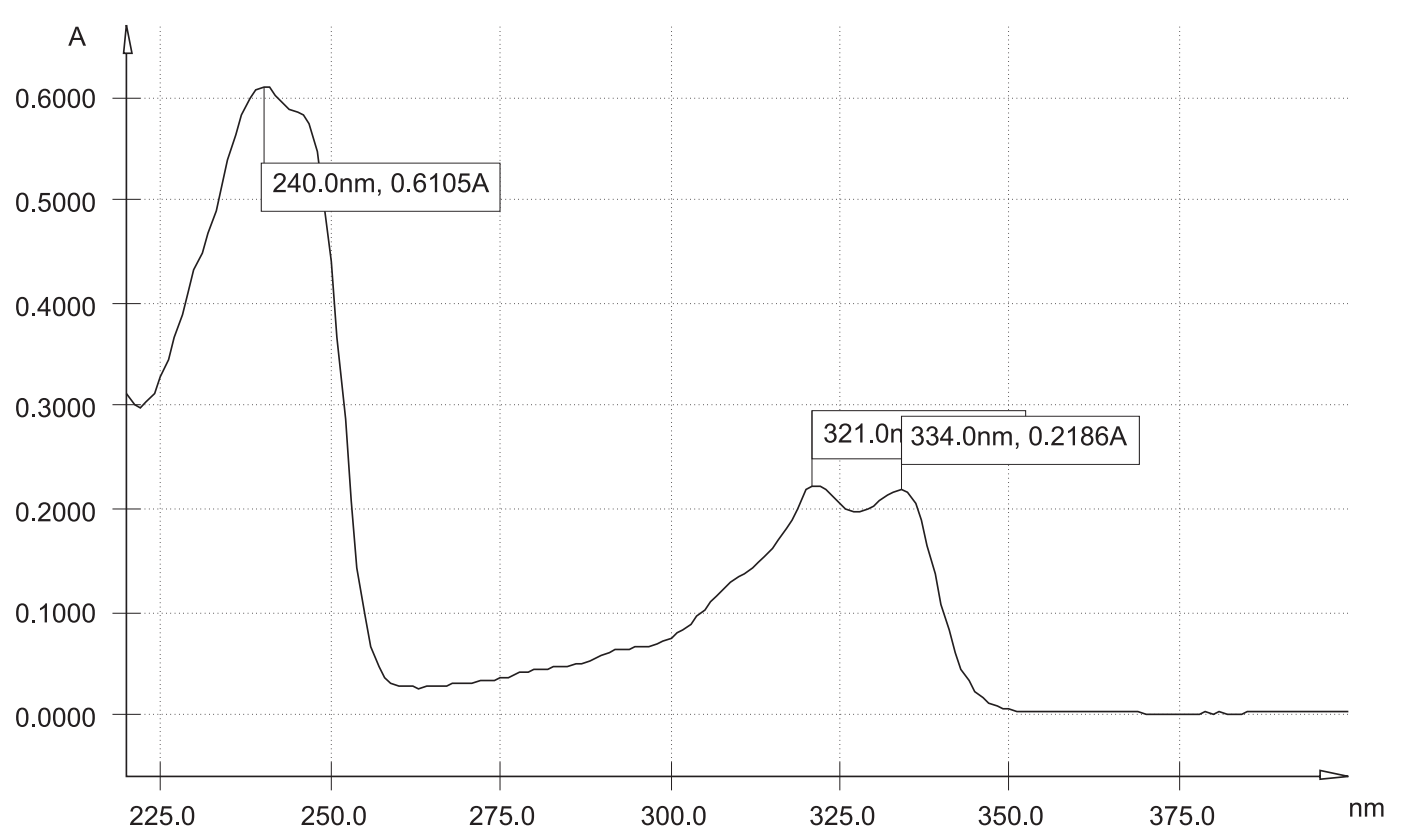

Absorbance

Fig. 9. The UV-spectrum of 3-(2-methyl-4-oxo-1,4-duhydroquinoline-3-yl) propanoic acid (0.0005\% solution in methanol).

- the multiple recrystallization from alcohols does not allow to obtain a chromatographically pure sample;

- to obtain reference standard (RS) of 3-(2-methyl4-oxo-1,4-dihydroquinoline-3-yl) propanoic acid the method of preparative chromatography should be used or other scheme of the synthesis should be developed;

- liquid chromatography is the only suitable method for quantitative determination of the substance, but the use of titrimetric determination (alkalimetry) is limited by the presence of hydroxyl groups in the structures of impurities $A$ and $B$.
The SPhU stipulates the use of UV (2.2.25) and IR (2.2.24) spectroscopy for the analysis of medicines. In order to assess feasibility and usefulness of applying these methods in development of quality control methods for prospective APIs among 4-oxo-quinoline-3-alkylcarboxylic acids the spectral studies of 3-(2-methyl-4-oxo-1,4dihydpoquinoline-3-yl) propanoic acid were conducted.

The UV-spectrum of absorption of $0.0005 \%$ methanolic solution of acid $\mathbf{1}$ has three absorption maximum at $240 \pm 2 \mathrm{~nm}, 321 \pm 2 \mathrm{~nm}$ and $334 \pm 2 \mathrm{~nm}$ (Fig. 9). The maxima at 321 and $334 \mathrm{~nm}$ have the incomplete nature, and the spectrum itself might be considered as a batho chromically displaced spectrum of benzene, which $\alpha$-band

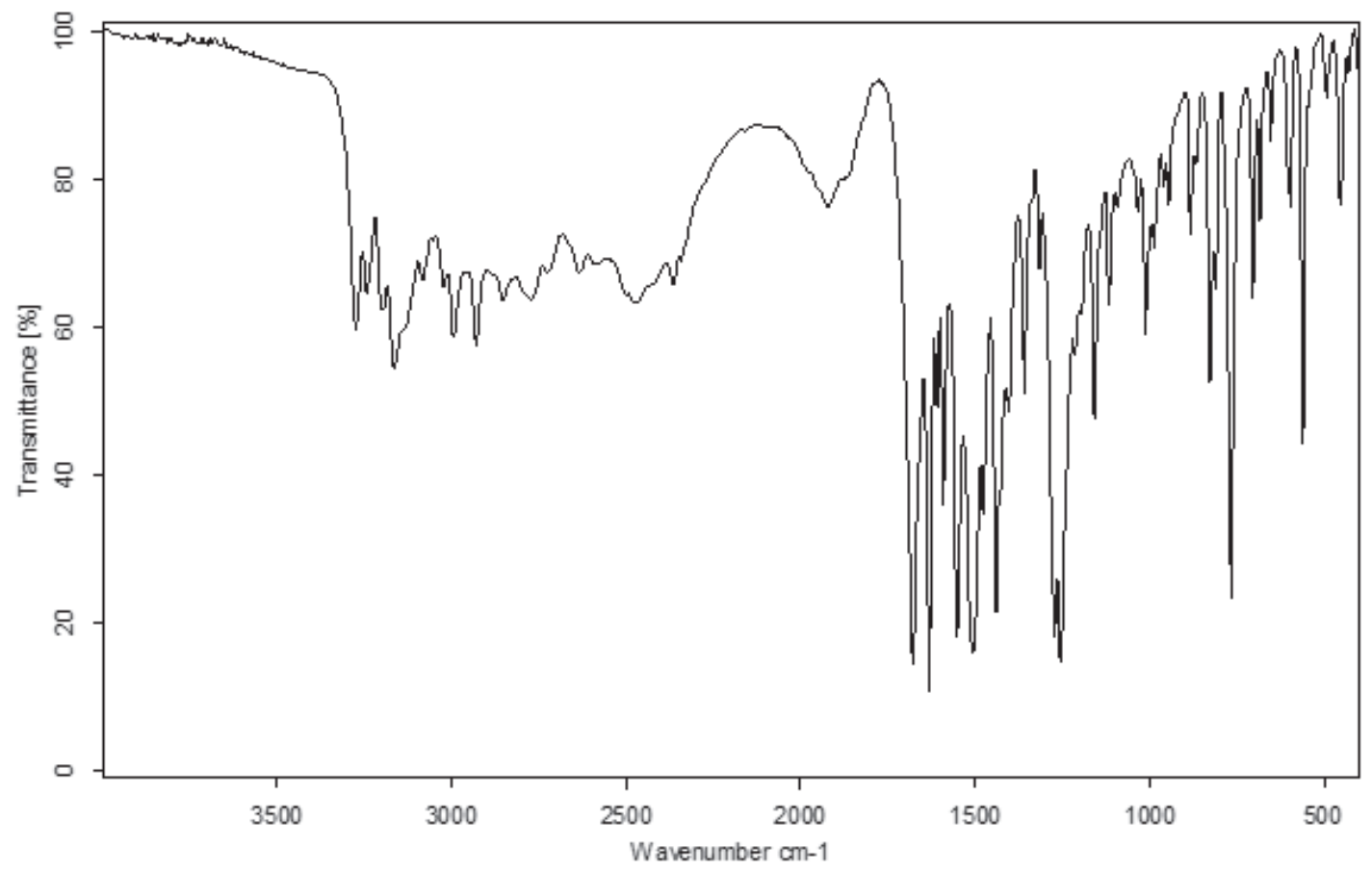

Fig. 10. The IR-spectrum of 3-(2-methyl-4-oxo-1,4-duhydroquinoline-3-yl) propanoic acid in a disk with potassium bromide (1:200). 
does not have a typical fine structure due to the superposition of absorption bands of $n \rightarrow \pi^{*}$ transitions. In view of the fact that while analyzing fluoroquinolones the USP, $\mathrm{Ph}$. Eur. and SPhU prefer other physical and chemical methods of analysis (Fig. 2), and the UV spectroscopy is used only for the analysis of dosage forms of fluoroquinolone preparations, as well as taking into account the uninformative nature of the UV spectrum for 3-(2methyl-4-oxo-1,4-dihydpoquinoline-3-yl) propanoic acid, we do not recommend the UV-spectroscopy method for development of quality control methods for derivatives of 4-oxo-quinoline-3-alkylcarboxylic acids.

The IR-spectrum of 3-(2-methyl-4-oxo-1,4-dihydroquinoline-3-yl) propanoic acid (Fig. 10) is characterized by the distinctively expressed bands of valence symmetric and asymmetric $v \mathrm{CH}$ bonds at $3300-2800 \mathrm{~cm}^{-1}$ The presence of the propionic acid fragment in the structure of aliphatic methylene groups causes the increase in the height of the peaks in this area. In the IR spectrum of the substance the characteristic valence vibrations of $v \mathrm{C}=\mathrm{O}$ groups are observed. At $1678 \mathrm{~cm}^{-1}$ the signals of $\mathrm{\nu C}=\mathrm{O}$ of the carboxyl group of the substance studied occur. At $1630 \mathrm{~cm}^{-1}$ there is the absorption peak of the $v \mathrm{C}=\mathrm{O}$ group of the quinoline cycle. Basically, the valence carbonyl vibrations of the carboxyl group of aliphatic alkanoic acids cause bands at $1700-1720 \mathrm{~cm}^{-1}$.

The bathochromic shift of the carboxyl group signal at $1678 \mathrm{~cm}^{-1}$ may be connected with the existence of the substance studied in a dimer form in the crystalline state. The valence vibrations of bonds of the $v C=C$ benzene fragment of the quinolone heterocycle appear at $1608-1591 \mathrm{~cm}^{-1}$. The method of IR-spectroscopy can be recommended when developing the quality control methods for derivatives of 4-oxo-quinoline-3-alkylcarboxylic acids in "Identification" section compared to the spectrum of the substance studied with the IR-spectrum of RS.

\section{CONCLUSIONS}

1. Based on the analysis of articles for fluoroquinolone antibiotics from the Pharmacopoeias of United States, Europe and Ukraine it is recommended to use such instrumental methods of analysis as IR, NMR-spectroscopy and liquid chromatography for development of quality control methods of promising APIs among derivatives of 3-(2-methyl-4-oxo-1,4-dihydroquinoline-3-yl) propanoic acids. ${ }^{13} \mathrm{C}$ NMR-spectroscopy is the necessary method of analysis, which allows solving uniquely the problem of the structural isomerism of 3-(2-methyl-4-oxo-1,4-dihydroquinoline-3-yl) propanoic acid.

2. Specific related substances of 3-(2-methyl-4-oxo1,4-dihydroquinoline-3-yl) propanoic acid have been determined using liquid chromatography-mass spectrometry (LC-MS/MS). Impurities - 1,2,3,4,9,10-hexahydroacridine-2,9-dione and 6a-hydroxy-5,6,6a, 8,9,14,15,16a,17, 18-decahydro-7,16-dioxa-5,14-diazaheptacen-9,18-dione appear as by-products in the results of the basic substance synthesis.

3. IR-spectroscopy can be recommended for development of quality control methods for 3- (2-methyl-4oxo-1,4-dihydroquinoline-3-yl) propanoic acid in "Identification" section. Meanwhile, the use of UV-spectroscopy does not seem appropriate for this purpose.

\section{REFERENCES}

1. Державна фармакопея України / Державне підприємство «Науково-експертний фармакопейний центр». 1-е вид. - Доп. 2. - Х.: РІРЕГ, 2008. - 617 c.

2. Державна фармакопея України / Державне підприємство «Науково-експертний фармакопейний центр». 1-е вид. - Доп. 4. - Х.: РІРЕГ, 2011. - 538 c.

3. 2016 U.S. Pharmacopoeia-National Formulary [USP 39 NF 34]. Vol. 1. Rockville, Md: United States Pharmacopeial Convention, Inc, 2015.

4. Deak D., Outterson K., Powers J.H. et al. // Annals of Internal Medicine. - 2016. - Vol. 165, №5. - P. 363.

5. European Pharmacopoeia, 8-th ed. Directorate for the Quality of Medicines and Healthcare of the Council of Europe. - Strasbourg, France, 2013. - P. 1231.

6. Global Action Plan on Antimicrobial Resistance / WHO. - 2015.

7. Günther H. NMR-spectroscopy: basic principles, concepts and applications in chemistry. - John Wiley \& Sons, 2013.

8. JChem 16.11.14.0, 2016, ChemAxon. (http://www.chemaxon.com).

9. Maggiora, Vogt M., Stumpfe D., et al. // J. of Med. Chem. - 2014. - Vol. 57, №8. - P. 3186-3204.

10. Premanandh J., Samara B.S., Mazen A.N. // Frontiers in Microbiol. - 2015. - Vol. 6. - P. 1536.

11. Santajit S., Indrawattana N. // BioMed Res. International. - 2016. - Vol. 2016. - P. 1-8.

12. Zubkov V.O., Osolodchenko T.P., Ruschak N.I. et al. // J. of Organic and Pharmac. Chem. - 2015. - Vol. 13, №4 (52). - P. 20-26.

13. Zubkov V.O., Rozhenko O.B., Ruschak N.I. et al. // J. of Organic and Pharmac. Chem. - 2011. - Vol. 14, №2. P. 53-59.

14. Zubkov V.O., Tsapko T.O., Gritsenko I.S et al. // J. of Organic and Pharmac. Chem. - 2011. - Vol. 9, №4. P. 38-41. 


\section{ЗАСТОСУВАННЯ АНАЛІТИЧНИХ МЕТОДІВ ДЛЯ КОНТРОЛЮ ЯКОСТІ ПЕРСПЕКТИВНИХ АКТИВНИХ ФАРМАЦЕВТИЧНИХ ІНГРЕДІЄНТІВ СЕРЕД ПОХІДНИХ 4-ОКСО-ХІНОЛІН-3- ПРОПАНОВИХ КИСЛОТ \\ В.О.Зубков, Н.І.Рущак, М.М.Сулейман, А.О.Девяткіна, І.С.Гриценко}

Ключові слова: антимікробна стійкість; хінолін-4-он; пропанова кислота; стандартизація; контроль якості; NMR; LC-MS/MS

У зв'язку з глобальним збільшенням стійкості мікроорганізмів до антимікробних препаратів пошук нових антибіотиків $є$ життєво важливим завданням сучасної медичної хімії. 3-Хінолін4-он-пропанові кислоти мають молекулярну подібність до фрторхінолонових антибіотиків i $є$ перспективними скаффролдами для створення антимікробних препаратів. На прикладі 3-(2-метил-4-оксо-1,4-дигідрохінолін-3-іл)пропанової кислоти проаналізовані і апробовані аналітичні методи, які можуть бути застосовані при контролі якості перспективних АФІ серед похідних 3-(2-метил-4-оксо-1,4-дигідрохінолін-3-іл) пропанових кислот. Показана необхідність включення до переліку методів контролю ${ }^{13} \mathrm{C}$ ЯМР-спектроскопії, за допомогою якої однозначно вирішується питання таутомерних фоорм 3-(2-метил-4-оксо-1,4-дигідрохінолін3-іл) пропанової кислоти. За допомогою рідинної хромато-мас-спектрометрії (LC-MS/MS) встановлені специфрічні супутні речовини, які є побічними продуктами синтезу 3-(2-метил4-оксо-1,4-дигідрохінолін-3-іл)пропанової кислоти - 1,2, 3, 4,9, 10-гексагідроакридин-2, 9-діон і 6а-гідрокси-5, 6,6а, 8,9,14,15,16а, 17,18-декагідро-7,16-діокса-5,14-діазагептацен-9,18-діон. Запропоновані рекомендації щодо використання УФ- та 1Ч-спектроскопій для розробки методів контролю якості 3-(2-метил-4-оксо-1,4-дигідрохінолін-3-іл)пропанової кислоти.

\section{ПРИМЕНЕНИЕ АНАЛИТИЧЕСКИХ МЕТОДОВ ДЛЯ КОНТРОЛЯ КАЧЕСТВА ПЕРСПЕКТИВНЫХ АКТИВНЫХ ФАРМАЦЕВТИЧЕСКИХ ИНГРИДИЕНТОВ СРЕДИ ПРОИЗВОДНЫХ 4-ОКСО-ХИНОЛИН-3-ПРОПАНОВЫХ КИСЛОТ}

В.А.Зубков, Н.И.Рущак, М.М.Сулейман, А.А.Девяткина, И.С.Грищенко

Ключевые слова: антимикробная устойчивость; хинолин-4-он; пропановая кислота; стандартизация; контроль качества; NMR; LC-MS/MS

В связи с глобальным увеличением устойчивости микроорганизмов к противомикробным препаратам поиск новых антибиотиков является жизненно важной задачей современной медицинской химии. 3-Хинолин-4-он пропановые кислоты имеют молекулярную схожесть с фрторхинолоновыми антибиотиками и являются перспективными скафрфолдами для создания противомикробных препаратов. На примере 3-(2-метил-4-оксо-1,4-дигидрохинолин-3ил)пропановой кислоты проанализированы и апробированы аналитические методы, которые могут быть применены при контроле качества перспективных АФИ среди производных 3-(2-метил-4-оксо-1,4-дигидрохинолин-3-ил)пропановых кислот. Показана необходимость включения в перечень методов контроля ${ }^{13} \mathrm{C}$ ЯМР-спектроскопии, с помощью которой однозначно решается вопрос о таутомерных формах 3-(2-метил-4-оксо-1,4-дигидрохинолин3-ил)пропановой кислоты. С помощью жидкостной хромато-масс-спектрометрии (LC-MS/MS) установлены специфические сопутствующие вещества, которые являются побочными продуктами синтеза 3-(2-метил-4-оксо-1,4-дигидрохинолин-3-ил)пропановой кислоты 1,2,3,4,9,10-гексагидроакридин-2, 9-дион и 6а-гидрокси-5, 6, 6а, 8, 9, 14, 15, 16а, 17,18-декагидро7,16-диокса-5, 14-диазагептацен-9, 18-дион. Предложены рекомендации по использованию УФ- и ИК-спектроскопий для разработки методов контроля качества 3-(2-метил-4-оксо-1,4дигидрохинолин-3-ил)пропановой кислоты. 